REPORTS OF MORPHOLOGY
$\begin{gathered}\text { Official Journal of the Scientific Society of Anatomists, } \\ \text { Histologists, Embryologists and Topographic Anatomists } \\ \text { of Ukraine } \\ \text { journal homepage: https://morphology-journal.com }\end{gathered}$

\title{
Micro- and ultrastructural organization of the uterine wall of a white laboratory rat under conditions of 4-week action of Nalbuphine
}

Ivankiv Ya.T.

Danylo Halytsky Lviv National Medical University, Lviv, Ukraine

\section{ARTICLE INFO}

Received: 16 December, 2019

Accepted: 20 January, 2020

UDC: $611-092.4 / .9: 615.212$

\section{CORRESPONDING AUTHOR}

e-mail: yarynkamandarynka@gmail.com Ivankiv Ya.T.

\begin{abstract}
The world community is facing a problem that threatens the entire population of the planet - reproductive health. This is a multifactorial problem that requires an integrated approach and effective solutions. One of the important factors that is very difficult to control and which in itself is a problem, and its prevalence can be called an epidemic without exaggeration, is drug addiction. The solution of these problems determined the purpose of our work - to establish what changes occur at the micro- and ultrastructural levels under the action of opioids on the uterus of white laboratory rats. The method of hematoxylin-eosin staining was used for histological examination, and the method of electron microscopy was used for the study at the cellular level. After 4 weeks of administration of Nalbuphine to white laboratory rats on histological sections, significant changes were observed in all layers of the uterus. The vessels of the myometrium were dilated, overflowing with erythrocytes, sometimes containing neutrophils and lymphocytes, perivasally marked the appearance of macrophages, in the cytoplasm of which was golden-brown pigment. The development of vacuolar dystrophy was also observed in the myometrium. There were necrotic changes and vacuolar dystrophy in the epithelium of the uterine mucosa, and epitheliocytes in which necrotic changes occurred exfoliated into the lumen of the uterus. The outer surface of the perimetrium was uneven due to necrotic changes of the monolayer squamous epithelium. Hyperplasia of the stratified squamous epithelium was observed in the ectocervix, in the areas of which a chaotic accumulation of low-differentiated epithelial cells was found. Electron microscopy revealed that a significant number of smooth myocytes lost their characteristic process shape, their nuclei were deformed and were in the stage of apoptosis, karyopyknosis and even karyorrhexis. The nucleoplasm contained almost no nucleoli, and heterochromatin is located on the periphery of the nucleus. The enlightened cytoplasm is filled with myofilaments, which are randomly arranged in the cell. Mitochondria acquired various shapes and sizes, mostly with destroyed cristae and areas of enlightenment. Swollen connective tissue layers between myocytes testify to circulatory disorders. The damage described in the experiment at all levels indicates the destructive effect of Nalbuphine, which causes irreversible changes that lead to significant violations of the structure and function of the uterus, which leads to the conclusion that excessive drug use has a direct negative impact on the reproductive system.

Keywords: uterus, structure, opioids, experiment, reproductive health.
\end{abstract}

\section{Introduction}

Global key issues have formed in the world community, which have not lost their relevance over the years. One such issue is the problem of reproductive health. According to the UN Declaration by definition (Cairo, 2014), it is a state of complete physical, mental and social well-being in all matters concerning the functions and processes of the reproductive system, including harmony in psychosexual relations in the family and reproduction [18]. Unfortunately, according to the $\mathrm{WHO}$, Ukraine is one of the last European countries in terms of natural population growth. This situation is due not only to economic and sociopsychological factors, but also the state of reproductive health of the population and women in particular [16]. After all, a healthy woman gives birth to a healthy child, and she has healthy offspring, and so the circle closes. Along with this, modern society has acquired a much newer, but no 
less global problem - the problem of drug addiction [5, 11]. In 2016, 19.5 million women (or 15.4\%) aged 18 and older used illicit drugs $[1,12]$. According to the report of the Center for Medical Statistics of the Ministry of Health of Ukraine for 2018, 3830 people were diagnosed with a first-time diagnosis of mental and drug-related behavioral disorders, 2299 of them used opioids, a total of 60686 people at the end of the year, including 40618 were opioid addicts. The vast majority are people of reproductive age from 15 to 35 years [6].

The aim of the study was to establish changes in the structural organization of the uterine wall of white laboratory rats at the micro- and ultrastructural levels under conditions of 4-week exposure to Nalbuphine.

\section{Materials and methods}

The study was performed on 16 adult white female rats aged 3.0-3.5 months and an initial body weight of 160-180 g. All animals were divided into 2 groups: the first (experimental) group of animals was administered intramuscularly Nalbuphine daily for four weeks (first week - $8 \mathrm{mg} / \mathrm{kg}$, the second week - $15 \mathrm{mg} / \mathrm{kg}$, the third week $-20 \mathrm{mg} / \mathrm{kg}$, the fourth week - $25 \mathrm{mg} / \mathrm{kg}$ ), and the second (control) group of animals during the experiment was injected with $0.9 \% \mathrm{NaCl}$ solution.

All animals were kept in the vivarium of Danylo Halytsky Lviv National Medical University, experiments were conducted in accordance with the provisions of the European Convention for the Protection of Vertebrate Animals Used for Experimental and Other Scientific Purposes (Strasbourg, 1986), Council of Europe Directive 2010/63/EU, Law of Ukraine № 3447 - IV "On protection of animals from cruel treatment". The materials of the work were considered by the members of the commission on bioethics of Danylo Halytsky Lviv National Medical University, who reached the agreed opinion that the materials submitted for examination are scientifically substantiated (Minutes № 9 of 31.10.2017).

Animals were removed from the experiment 4 weeks after the introduction of the opioid through euthanasia by overdose of diethyl ether.

Hematoxylin-eosin staining was used for histological examination. Preparations of the uterus of a female white rat were fixed in a $10 \%$ neutral solution of formalin, and then clarified in alcohols of various concentrations. It was later immersed in xylene and then in xylene/paraffin, the paraffin blocks were poured into a mold, cooled with water and $7 \mu \mathrm{m}$ thick paraffin sections were cut with a knife. The slice was dried in a thermostat at a temperature of $37-$ $40^{\circ} \mathrm{C}$. Staining was performed according to standard methods [7].

For electron microscopy, the samples were fixed with a $1.5 \%$ solution of $\mathrm{OsO}_{4}$ (Osmium Tetroxide SPI - CHEM USA) in a $0.2 \mathrm{M}$ solution of sodium cacodylate (Cacodylic acid Sodium salt. Fluka) at $\mathrm{pH} 7.2$ for $2-2.5$ hours in the cold. Dehydration in increasing concentrations of ethyl alcohol $\left(50^{\circ}, 70^{\circ}, 90^{\circ}\right.$ and absolute) for 30 minutes each. Conduction through propylene oxide (Fluka) for 10 minutes
Pouring samples into epoxy resins Epon-812 (Fluka) and polymerization for 24 hours in a thermostat at $60^{\circ} \mathrm{C}$. Sections were prepared on an ultramicrotome UMTP-6M using a diamond knife (DIATOM). Contrast sections in 1\% uranyl acetate solution and in Reynolds contrast. Photographing of uterine structures was performed using a microscope UEMV-100K at an accelerating voltage of $75 \mathrm{kV}$.

\section{Results}

Histological examination of the uterus at 4 weeks of experimental administration of Nalbuphine in the epithelium of the mucous membrane of the uterine horns revealed necrotic changes and vacuolar dystrophy, namely, in the cytoplasm of epithelial cells marked enlightenment of the cytoplasm, the appearance of small rounded vacuoles. Epitheliocytes, in which necrotic changes took place, exfoliated into the lumen of the uterus. Also found the development of vacuolar dystrophy, increasing dyscirculatory changes in the vascular system of the myometrium. Small arteries and veins of the myometrium were dilated, filled with erythrocytes, sometimes containing neutrophils and lymphocytes (Fig. 1).

Due to necrotic changes of the myometrium, the outer surface of the perimetrium was uneven. The own mucosal plate was infiltrated by lymphocytes, single neutrophils and eosinophils. The appearance of macrophages in the cytoplasm of which a golden-brown pigment was localized was noted in the connective tissue stroma around the vessels (Fig. 2).

In the ectocervix of the cervix, which is represented by a multilayered squamous epithelium, its hyperplasia was observed, in the areas of which a chaotic accumulation of low-differentiated epithelial cells was seen (Fig. 3).

In the myometrium of the cervix noted hyperemia and blood stasis, as well as the progression of alternative changes in smooth myocytes. Polymorphonuclear infiltration of the myometrial stroma also developed.

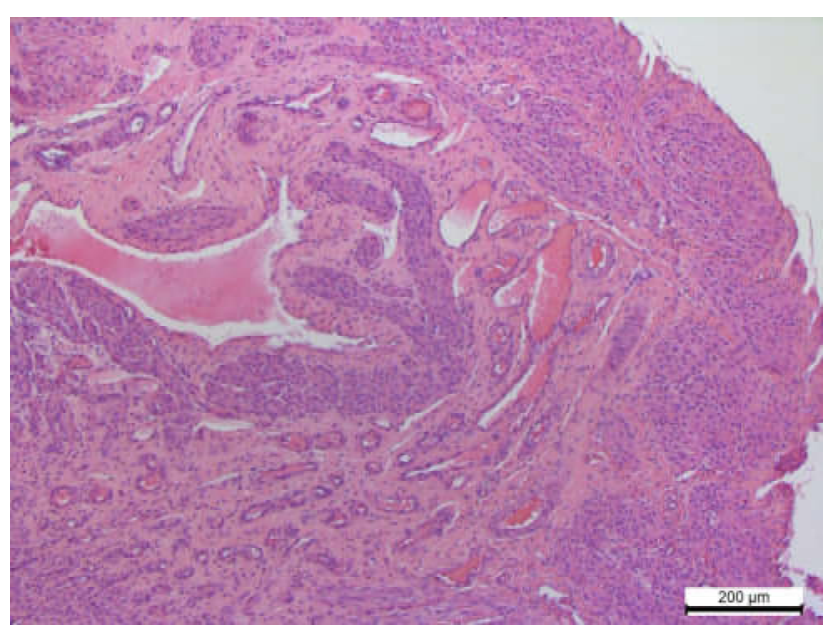

Fig. 1. The hyperemia of vessels of a myometrium of a uterine horn is expressed. Necrotic changes of the monolayer squamous epithelium of the myometrium. Hematoxylin and eosin. x100. 


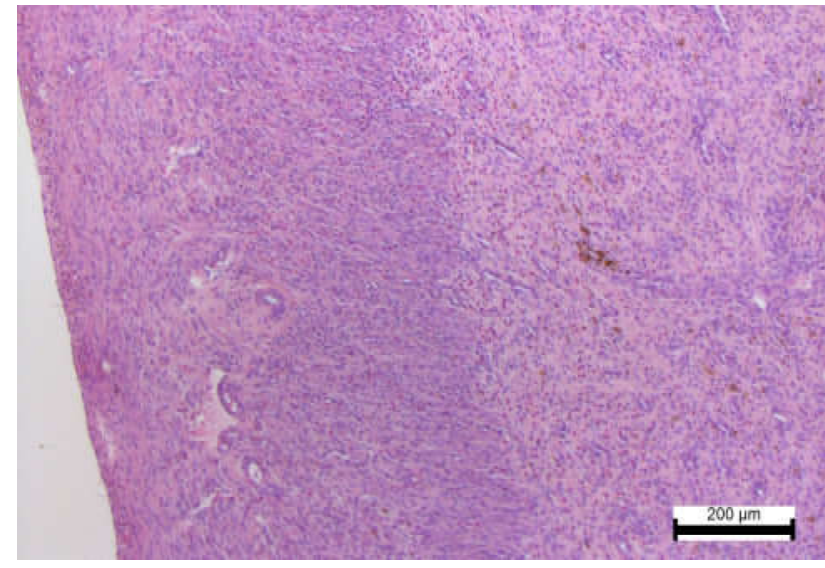

Fig. 2. Polymorphonuclear infiltration of the myometrium. Brownyellow pigment inclusions in the cytoplasm of macrophages. Hematoxylin and eosin. x100.

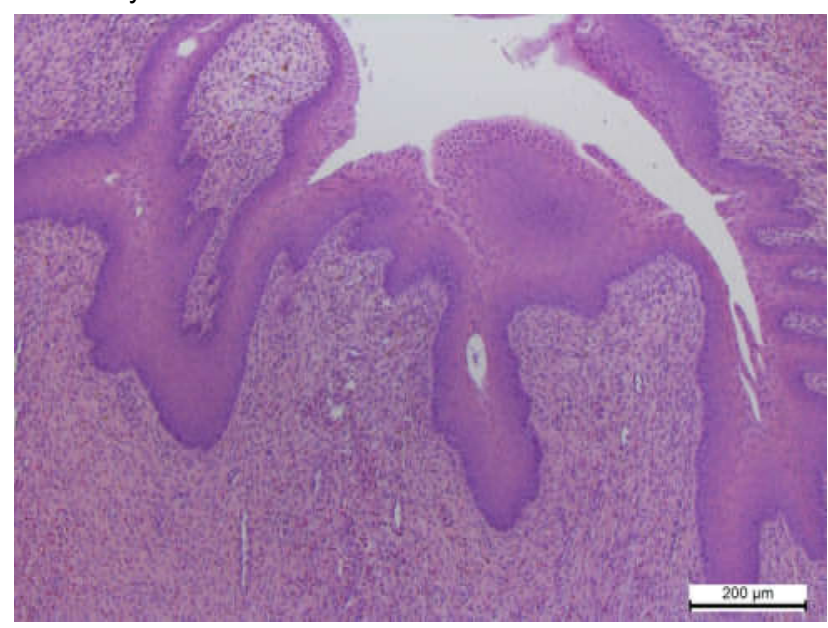

Fig. 3. Hyperplasia and violation of cell differentiation of the multilayered squamous epithelium of the vaginal part of the cervix (ectocervix). Hematoxylin and eosin. x100.

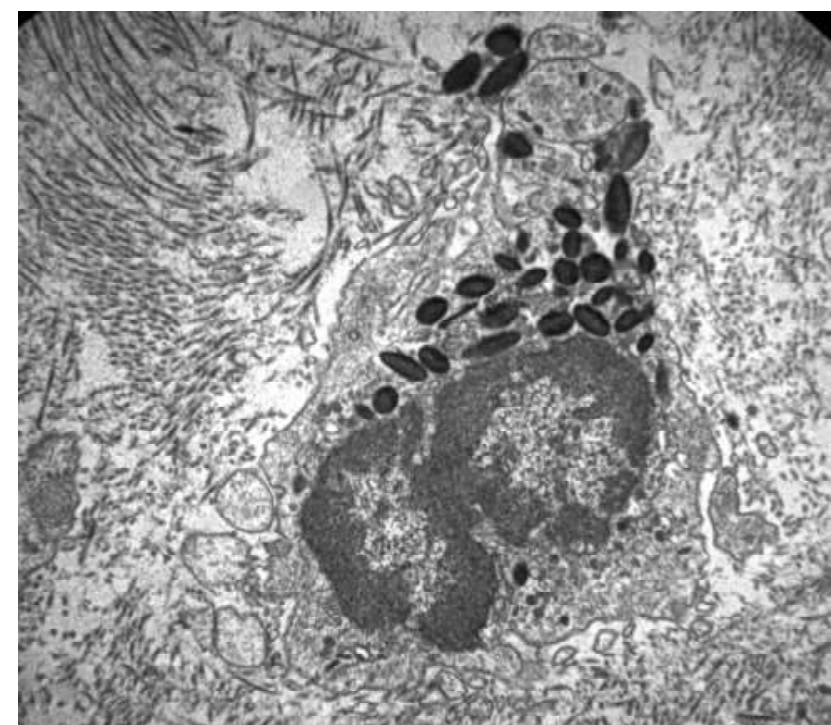

Fig. 4. Fragment of the uterine wall of a white laboratory rat after 4 weeks of Nalbuphine administration. Electronic microphotography. $\mathrm{x} 8000$.
Neutrophils and macrophages predominated in the infiltrates, and eosinophils and lymphocytes were somewhat less common.

The study by electron microscopy revealed significant changes in the ultrastructural organization of the uterus of white laboratory rats under conditions of 4-week administration of Nalbuphine. A significant number of smooth myocytes lost their characteristic process shape, their nuclei were deformed and were in the stage of apoptosis, karyopyknosis and even karyorrhexis (Fig.4).

In the nucleoplasm there are almost no nucleoli, heterochromatin, which predominates, is located on the periphery of the nucleus. The cytoplasm is enlightened and filled with myofilaments, which are randomly arranged in the cell. Mitochondria come in different shapes and sizes, mostly with destroyed cristae and areas of enlightenment. Connective tissue layers between myocytes are swollen, which is characteristic of circulatory disorders.

\section{Discussion}

In today's world, where there is unrestricted access to anything, the problems of drug addiction and the state of reproductive health of the population, closely intertwined with each other, are acute for the world community. Drug control over pharmacotherapy is becoming more stringent every year, and international health organizations are working intensively to develop effective programs for the prevention, control and treatment of drug addiction [14, 15]. In fact, opioids occupy a leading position among all groups of drugs that are abused, as they are widely used in medical practice.

After analyzing the professional literature, it was found that this group of drugs has a negative effect on the female genitals [2, 8]. A number of authors have described the effect of different groups of opioids on pregnant female rats, namely on the muscular membrane of the uterus - the myometrium, where a violation of the contractile ability of the uterine muscles $[9,17]$.

Maryam Dehghan et al., who described changes in the micro- and ultrastructural changes in the uterus of pregnant rats under the influence of morphine, made a significant contribution to the study of the female reproductive organ, the uterus. Light microscopy revealed the following histological changes: inflammatory polymorphic infiltration of the stroma, areas of apoptosis and overflowing and dilated vessels, electron microscopy observed deformation and destruction of the nuclear envelope of epithelial cells of the endometrium, the appearance of wide gaps between the nuclei and heterochromatin which is not typical in the control groups [3].

Heba Atef El-Ghawet conducted a study of the synthetic opioid tramadol on the reproductive system, which found that both the structure of the ovary and the quality of follicles in it deteriorated, ovarian dysfunction was confirmed by massive atrophy and dysfunction of the endometrial glands [4]. Changes in muscle tissue at the ultrastructural level in 
the study of the effect of Nalbuphine on cardiomyocytes, showed the destruction of mitochondria, the expansion of the intercellular space, the marginal location in the nucleus of chromatin [13].

In general, the trend of negative destructive effects of opioid drugs has been observed in many scientific studies, but in order to get a complete picture and systematize the effects of opioids on the female reproductive system, including the uterus, additional targeted studies are needed [10].

In our work, a comprehensive morphological study of the uterus at the micro- and ultrastructural level on the background of long-term exposure to Nalbuphine using electron microscopic and histological methods, as well as features of the restructuring of the cell structure of this organ. The obtained results will expand the idea of quantitative and qualitative changes in the cellular composition of the uterus with the use of Nalbuphine and

\section{References}

[1] Adams, K. T., Adams, T., Aldworth, J., Asman, K. J., Barnett, S. N., \& Bishop, E. (2016). Results from the 2016 National Survey on Drug Use and Health: detailed tables. Center for Behavioral Health Statistics and Quality (CBHSQ), Substance Abuse and Mental Health Services Administration (SAMHSA), US Department of Health and Human Services (HHS), RTI International.

[2] Benningfield, M. M., Dietrich, M. S., Jones, H. E., Kaltenbach, K., Heil, S. H., Stine, S. M., ... Martin, P. R. (2012). Opioid dependence during pregnancy: relationships of anxiety and depression symptoms to treatment outcomes. Addiction, 107, 74-82. doi: 10.1111/j.1360-0443.2012.04041.x

[3] Dehghan, M., Jafarpour, M., \& Mahmoudian, A. R. (2010). The effect of morphine administration on structure and ultrastructure of uterus in pregnant mice. Iranian Journal of Reproductive Medicine, 8(3), 111-118.

[4] El-Ghawet, H. A. (2015). Effects of tramadol on the reproductive function of wistar albino rats. Eur. J. Exp. Biol., 5, 56-64. Available online at www.pelagiaresearchlibrary.com

[5] Gorman, M. C., Orme, K. S., Nguyen, N. T., Kent III, E. J., \& Caughey, A. B. (2014). Outcomes in pregnancies complicated by methamphetamine use. American Journal of Obstetrics and Gynecology, 211(4), 429-e1. doi: 10.1016/ j.ajog.2014.06.005

[6] Government agency "Center for Mental Health and Monitoring of Drugs and Alcohol of the Ministry of Health of Ukraine" (2018). National report on the drug situation in Ukraine for 2018 (according to 2017). Kyiv. http://cmhmda.org.ua

[7] Horalskyi, L. P., Khomych, V. T., \& Kononskyi, O. I. (2011). Fundamentals of histological technique and morphofunctional research methods in normal and pathology. Zhytomyr: Polissya.

[8] Ivankiv, Y. (2019). Structural organization of the links of hemomicrocircular channel of the rat's uterus under the conditions of 6-week long administration of Nalbuphine. Proceeding of the Shevchenko Scientific Society. Medical Sciences, 55(1), 111-117. doi: https://doi.org/10.25040/ ntsh2019.01.01

[9] Kayacan, N., Ertugrul, F., Arici, G., Karsli, B., Akar, M., \& Erman, M. (2007). In vitro effects of opioids on pregnant uterine muscle. Advances in therapy, 24(2), 368-375. doi: 10.1007/ its subsequent ability to perform reproductive function, as well as the ability of uterine cells to reparative and/or compensatory processes with drug withdrawal. This will allow us to review and improve the treatment of obstetric and gynecological diseases in women who are forced to use opioids for a long time or are drug addicts.

\section{Conclusions}

Prolonged exposure to Nalbuphine causes significant micro- and ultrastructural changes in the uterine wall. The injuries described in the experiment indicate a destructive effect that can cause irreversible changes, which in turn lead to significant violations of the structure and function of the uterus. Disorders that occur at all levels, from organelles to the level of organs and the system as a whole, prompt special attention to this problem, both scientists and practitioners.

\section{BF02849906}

[10] Mateshuk-Vatseba, L. R., Ivankiv, Ya. T., \& Ivankiv, T. M. (2019). The influence of opioid on the microstructural organization of the Wall OT the uterus of the white laboratory rat. Clin. J. Obstet. Gynaecol., 2, 135-137. doi: dx.doi.org/10.29328/ journal.cjog.1001036

[11] McHugh, R. K., DeVito, E. E., Dodd, D., Carroll, K. M., Potter, J. S., Greenfield, S. F., ... Weiss, R. D. (2013). Gender differences in a clinical trial for prescription opioid dependence. Journal of Substance Abuse Treatment, 45(1), 38-43. doi: 10.1016/ j.jsat.2012.12.007

[12] NIDA (2020). Substance Use in Women. Retrieved from https:/ /www.drugabuse.gov/publications/research-reports/ substance-use-in-women/sum

[13] Pokotylo, V. Yu. (2017). Ultrastructural features of rat myocardium and its hemomicrocirculatory bed at the early stages of opioid intoxication. Bulletin of Problems of Biology and Medicine, 1(135), 304-309.

[14] Substance Abuse and Mental Health Services Administration (SAMHSA). (2011). Addressing the needs of women and girls: Developing core competencies for mental health and substance abuse service professionals. U.S. Department of Health and Human Services.

[15] Wizemann, T. M., \& Pardue, M. L. (2001). Institute of Medicine (US) Committee on Understanding the Biology of Sex and Gender Differences. Exploring the biological contributions to human health: does sex matter. Washington (DC): National Academies Press (US).

[16] World Health Organization. Department of Mental Health, Substance Abuse, World Health Organization, International Narcotics Control Board, United Nations Office on Drugs, \& Crime. (2009). Guidelines for the psychosocially assisted pharmacological treatment of opioid dependence. World Health Organization.

[17] Yoo, K. Y., Lee, J., Kim, H. S., \& Jeong, S. W. (2001). The effects of opioids on isolated human pregnant uterine muscles. Anesthesia \& Analgesia, 92(4), 1006-1009. doi: 10.1097/ 00000539-200104000-00037

[18] Yuzko, O. M. (2016). Reproductive health benefits: medical and social aspects. Health, (6), 3-6. 


\section{МІКРО- ТА УЛЬТРАСТРУКТУРНА ОРГАНІЗАЦІЯ СТІНКИ МАТКИ БІЛОГО ЛАБОРАТОРНОГО ЩУРА ЗА УМОВ 4-ТИЖНЕВОЇ ДІї НАЛБУФІНУ \\ Іванків Я.Т.}

Світове суспільство зіштовхнулося з проблемою, яка становить загрозу для усього населення планети - репродуктивне здоров'я. Це є мультифракторіальною проблемою, яка потребує комплексного підходу та дієвих рішень. Одним із важливих чинників, який дуже складно контролювати та який сам по собі становить проблему, а його поширеність без перебільшень можна назвати епідемією, є наркоманія. Вирішення цих проблем зумовило мету нашої роботи - встановити, які зміни відбуваються на мікро- та ультраструктурних рівнях при дії опіоїду на матку білого лабораторного щура. Для гістологічного дослідження застосували метод забарвлення гематоксилін-еозином, для дослідження на клітинному рівні використовували метод електронної мікроскопії. Після 4 тижнів введення налбуфріну білим лабораторним щурам на гістологічних зрізах спостерігали значні зміни у всіх шарах матки. Судини міометрія були розширені, переповнені еритроцитами, подекуди містили нейтрофріли та лімфоцити, перивазально відзначали появу макрофааів, у цитоплазмі яких локалізувався пігмент золотисто-бурого кольору. Також у міометрії спостерігали розвиток вакуольної дистрофрії. В епітелії слизової оболонки рогів матки були некротичні зміни та вакуольна дистрофрія, а епітеліоцити, в яких відбулись некротичні зміни, злущувались у просвіт матки. Зовнішня поверхня периметрія була нерівною, внаслідок некротичних змін одношарового плоского епітелію. В ектоцервіксі спостерігали гіперплазію багатошарового плоского епітелію, в ділянках якої виявили хаотичне нагромадження низькодиференційованих епітеліальних клітин. Методом електронної мікроскопії було встановлено, що значна кількість гладких міоцитів втрачала характерну відростчасту фрорму, їхні ядра деформовані та перебували у стадії апоптозу, каріопікнозу та навіть каріорексису. Нуклеоплазма практично не містила ядерець, а гетерохроматин розташований по перифрерії ядра. Просвітлена цитоплазма виповнена міофріламентами, які хаотично розташовані у клітині. Мітохондрії набували різної фоорми та розмірів, переважно зі зруйнованими кристами та ділянками просвітлення. Про порушення кровообігу свідчили набряклі сполучнотканинні прошарки між міоцитами. Описані в експерименті пошкодження на усіх рівнях свідчать про деструктивний вплив налбуфріну, що спричиняє незворотні зміни, які призводять до значних порушень структури та функцій матки, що дозволяє зробити висновок, що надмірне вживання наркотичних речовин має безпосередній негативний вплив на органи репродуктивної системи.

Ключові слова: матка, структура, опіоїди, експеримент, репродуктивне здоров'я.

\section{МИКРО- И УЛЬТРАСТРУКТУРНАЯ ОРГАНИЗАЦИЯ СТЕНКИ МАТКИ БЕЛОЙ ЛАБОРАТОРНОЙ КРЫСЫ В УСЛОВИЯХ 4-НЕДЕЛЬНОГО ДЕЙСТВИЯ НАЛБУФИНА \\ Иванкив Я.Т.}

Мировое общество столкнулось с проблемой, которая представляет угрозу для всего населения планеты - репродуктивное здоровье. Это мультифракториальная проблема, требующая комплексного подхода и действенных решений. Одним из важных фракторов, который очень сложно контролировать и который сам по себе является проблемой, а его распространенность без преувеличения можно назвать эпидемией, является наркомания. Решение этих проблем обусловило цель нашей работы - установить, какие изменения происходят на микро- и ультраструктурных уровнях при воздействии опиоида на матку белой лабораторной крысы. Для гистологического исследования применили метод окрашивания гематоксилин-эозином, для исследования на клеточном уровне использовали метод электронной микроскопии. После 4 недель введения налбуфина белым лабораторным крысам на гистологических срезах наблюдали значительные изменения во всех слоях матки. Сосуды миометрия были расширены, переполнены эритроцитами, иногда содержали нейтрофилы и лимфоциты, перивазально отмечали появление макрофагов, в цитоплазме которых локализовался пигмент золотистобурого ивета. Также в миометрии наблюдали развитие вакуольной дистрофии. В эпителии слизистой оболочки рогов матки были некротические изменения и вакуольная дистрофия, а эпителиоциты, в которых выявлены некротические изменения, десквамировались в просвет матки. Внешняя поверхность периметрия была неровной вследствие некротических изменений однослойного плоского эпителия. В эктоцервиксе наблюдали гиперплазию многослойного плоского эпителия, 8 участках которого обнаружили хаотическое нагромождение низкодиффреренцированных эпителиальных клеток. Методом электронной микроскопии было установлено, что значительное количество гладких миоцитов теряло характерную отростчатую фрорму, их ядра были деформированы и находились в стадии апоптоза, кариопикноза и даже кариорексиса. Нуклеоплазма практически не содержала ядрышек, а гетерохроматин располагался по периферии ядра. Просветленная цитоплазма выполнена миофиламентами, которые хаотично расположены в клетке. Митохондрии приобретали различную форму и размеры, преимущественно с разрушенными кристами и участками просветления. О нарушении кровообращения свидетельствовали набухшие соединительнотканные прослойки между миоцитами. Описанные в эксперименте повреждения на всех уровнях свидетельствуют о деструктивном влиянии налбуффина, что вызывает необратимые изменения, которые приводят к значительным нарушениям структуры и функций матки, что позволяет сделать вывод, что чрезмерное употребление наркотических веществ имеет непосредственное негативное влияние на органы репродуктивной системы. Ключевые слова: матка, структура, опиоиды, эксперимент, репродуктивное здоровье. 